\title{
ノイズを含むデータから作成した応答曲面の予測精度*
}

\author{
竹 田 憲 生*1, 坂田 誠一郎*2
}

\section{Prediction Accuracy for Response Surfaces Generated Using Noisy Data}

\author{
Norio TAKEDA*3 and Sei-ichiro SAKATA \\ ${ }^{* 3}$ Mechanical Engineering Research Laboratory, Hitachi, Ltd. \\ 832-2 Horiguchi, Hitachinaka-shi, Ibaraki, 312-0034 Japan
}

\begin{abstract}
Response surfaces generated by using an artificial neural network or a Kriging model can approximate multimodal responses and the responses of multi-variable functions, even if the prior information used in creating the surfaces contains noises. To prevent the response surfaces from fitting to the noises in the prior information, regularization methods are applied. The Bayesian regularization method works well with an artificial neural network, and the improved nugget effect method can be effectively applied to the regularization of an ordinary Kriging model. Which response surface model to select depends on the amount of prior information and the number of variables in the response function. The Kriging model generates a more accurate response surface with a smaller amount of prior information than the artificial neural network does. On the other hand, the artificial neural network is more effective for approximating the response of a multivariable function than the Kriging model. As a result, we can apply the response surface method to find the variables that ensure the optimum response of a function. This may increase the opportunities for using optimization techniques in the practical design process.
\end{abstract}

Key Words : Neural Network, Kriging, Response Surface, Regularization, Optimization

\section{1. 粕 言}

$\mathrm{Box}^{(1)}$ が実験計画法を設計に利用して以来, 既知のデ 一タを使ってある現象の振る舞いを近似するモデルを 作成し，それを使って最適化を行う方法が盛しに研究 されてきた. その近似モデルは応答曲面と呼ばれ，一 般的には多項式が使われるが，近年では応答曲面に二 ユーラルネットワーク（Neural Network : 以降, NN と 略記する) (2)，RBF（Radial Basis Function) ${ }^{(3)}$ ，クリギ ング(4)(5)も積極的に使われている，その中でも特に, $\mathrm{RBF}$ やクリギングは多項式と比べて柔軟な近似性能 を有することが指摘され(6)，任意の写像関係を近似可 能な $\mathrm{NN}^{(8)}$ と同様に様々な適用例が報告されている.

ただし，これらの手法は複雑な写像関係を近似でき るがゆえに，実験データなどノイズを含むデータを利 用して応答曲面を作成すると，真の応答のみならず, ノイズまでも忠実に再現する応答曲面が作成される恐

* 原稿受付 2008 年 1 月 21 日.

*1 正員，(株) 日立製作所機械研究所(画312-0034 ひたちなか 市堀口 832-2)

*2 正員, 島根大学総合理工学部(画690-8504 松江市西川津町 1060).

E-mail : norio.takeda.uf @ hitachi.com
れがあることが指摘されている(9).

このような応答曲面のノイズへの過剩適合を避け, 適切な応答曲面を作成するための方法が各近似モデル に対して提案されている. クリギングの場合, Sasena らは適当なフィルタリングを行うことでサンプルデー 夕（既知のデータ）を通らない応答曲面を生成する方 法について議論している(10)．また, Sakata らはセミバ リオグラムに関する仮定を緩和する等の方法により， ノイズを含むデー夕に適用可能な通常（Ordinary）ク リギングとそれを用いた最適化方法を提案している (11).一方，NNに関しても，MacKay がベイズ推論に基 づく適切化によって，ノイズを含むデータへの NN の 適用可能性について議論している(12)(13).これらはいず れも独自の観点からノイズを含むデータに適用可能な 手法を構築しているため, 各方法がどのような応答曲 面の生成に適しており，有効であるかを検討した例は 無い.

そこで本論文では, ベイズ推論に基づくニューラル ネットワークおよびノイズを含むデー夕に適用可能な クリギングを使って応答曲面を作成し，その応答曲面 による真の応答の予測精度を比較検討する．さらに, 
それらを工学的最適化問題に適用し, 各ヶの手法の有 効性について検証する.

\section{2.ノイズに適合しない応答曲面の作成}

$2 \cdot 1$ ニューラルネットワークによる方法 = ユーラルネットワーク（以降， NN と記す）は一般的 に, NN の応答と既知データの応答の 2 乗誤差が最小 となるように学習される. NN の分野では, このよう な目的で使われる既知データを教師データと呼ぶ. 以 降ではNN に限らず同様の目的で使われるデータを教 師データと記述する。この教師データがノイズを含む 場合, 2 乗誤差を最小化する学習方法では, NN の構造 や学習回数を適切に定めないと, 学習後の NNによる 応答曲面はノイズに過剩適合する.これを避けるため に, MacKay はNN の学習にベイズ推論を適用する方 法を提案した ${ }^{(12)(13)}$. この方法では, 2 乗誤差に適切化 項を加えた次式を最小化することによって学習を行う.

$$
M=\beta E_{\mathrm{D}}+\alpha E_{\mathrm{W}}
$$

ここで, $E_{\mathrm{D}}$ はNNによる応答と教師データ応答の 2 乗 誤差である. また, $E_{\mathrm{W}}$ は応答曲面は滑らかである」 という事前知識を表す適切化項であり, 例えば次の関 数が用いられる.

$$
E_{W}=\sum_{i} \frac{1}{2} \boldsymbol{w}_{i}^{2}
$$

式中の $\boldsymbol{w}$ は NN の各素子間の重み係数である. また, $\alpha, \beta$ は超パラメータ ${ }^{(12)}$ と呼ばれており, ベイズ推論 に従うと次式で求められる.

$$
\alpha=\frac{\gamma}{2 E_{\mathrm{W}}}, \quad \beta=\frac{N-\gamma}{2 E_{\mathrm{D}}}
$$

$N$ は教師データの数に出力の数を乗じたものである. また, $\gamma$ は全ての重み係数のうち, 教師データによっ てうまく推定される係数の数である. この $\gamma$ の計算方 法は数通りあるが，次式の計算方法が有効に作用する ことが報告されている ${ }^{(14)}$.

$$
\gamma=\sum_{a=1}^{k} \frac{\lambda_{a}}{\lambda_{a}+\alpha}
$$

$k$ は重み倸数の数, $\lambda_{a}$ は行列 $\beta \boldsymbol{B} \quad\left(\boldsymbol{B}=\nabla \nabla E_{\mathrm{D}}\right)$ の固 有值である. $\alpha, \beta$ の推定を安定して行うため, $\lambda_{a}$ が負のときは $\lambda_{a}$ を 0 とする.

具体的には次のアルゴリズムで NN を学習する。
(I) 超パラメータの初期值 $\alpha^{(0)}, \beta^{(0)}$ を設定する.

(II) 超パラメータ $\alpha^{(0)}, \beta^{(0)}$ を式(1)に代入して NN を学習し, 重み係数の推定值 $\boldsymbol{w}^{(1)}$ を求める.

（III） $\boldsymbol{w}^{(1)}$ と超パラメータの算出式 (式(3)）を使い, 超パラメータの推定值 $\alpha^{(1)}, \beta^{(1)}$ を求める.

(IV) 以降, $\alpha^{(i-1)}, \beta^{(i-1)}$ を使った NN の学習による $\boldsymbol{w}^{(i)}$ の推定と, $\boldsymbol{w}^{(i)}$ と超パラメータの算出式によ る $\alpha^{(i)}, \beta^{(i)}$ の推定を収束するまで繰り返す。

( $i \geqq 2$ )

$2 \cdot 2$ クリギングによる方法 一般的なクリギン グで作成した応答曲面では，サンプル点（設計空間上 の教師データの位置) において, 応答曲面による応答 の予測值と教師データの応答值は完全に一致する. そ のため, 教師データがノイズを含む場合, 応答曲面に よる応答の予測值はノイズを含んだものとなり, 結果 として真の応答を予測することができない.このよう なノイズへの適合を防ぐ方法として，ナゲット効果を 導入したセミバリオグラム関数を使用する方法がある が，サンプル点で予測值が教師データの応答值と一致 するという特徵は保持されるため, 予測曲面が不連続 となる ${ }^{(15)}$. これに対し Sakata らは，応答曲面に関する セミバリオグラム関数を修正するとともに，セミバリ オグラムパラメータの決定に利用する経験セミバリオ グラムにおいてデータのばらつきを考慮することで, ノイズを含むデータにも適用可能な方法 (Noise-

resistant Smoothed Kriging，以降 ns-Kriging と略記する) を提案した ${ }^{(11)}$.

ns-Kriging による応答の予測式は一般的な通常クリ ギングと同様に次式で与えられる.

$$
f\left(x_{0}\right)=\sum_{i} f_{i} w_{i}=\sum_{i} f\left(x_{i}\right) w\left(x_{i}, x_{0}\right)
$$

ただし，

$$
w=\Gamma^{-1} \gamma^{*}+\frac{1-1 \Gamma^{-1} \gamma^{*}}{1 \Gamma^{-1} 1} \Gamma^{-1} 1
$$

である. ここで, 1 は全ての要素が 1 のベクトル， $\Gamma$ および ${ }^{*}$ はセミバリオグラム関数からなるマトリッ クスおよびべクトルである. $\boldsymbol{\Gamma}$ の要素 $\gamma\left(\boldsymbol{x}_{i}-\boldsymbol{x}_{j}\right)$ はサ ンプル点データに関するセミバリオグラム関数 ${ }^{(16)}$ で あり, Gauss 型を仮定した場合, 次式で与えられる. 


$$
\gamma=\left\{\begin{array}{c}
\beta_{0}+\beta_{1}\left[1-\exp \left(-\left\{\frac{\left|\boldsymbol{h}_{i j}\right|}{\beta_{2}}\right\}^{2}\right)\right] \\
0
\end{array} \begin{array}{l}
: \boldsymbol{h}_{i j} \neq 0 \\
: \boldsymbol{h}_{i j}=0
\end{array}\right.
$$

ここで $h_{i j}=x_{i}-x_{j}, \beta_{i}$ はセミバリオグラムパラメー タである. 一方, $\gamma^{*}$ は予測曲面に関する次式のセミバ リオグラム関数である.

$$
\gamma^{*}\left(\boldsymbol{h}_{i} ; \boldsymbol{\beta}\right)=\beta_{0}+\beta_{1}\left[1-\exp \left(-\left\{\frac{\left.\left|\boldsymbol{h}_{i}\right|\right|^{2}}{\beta_{2}}\right\}^{2}\right)\right]
$$

ns-Kriging では, 式(7), (8)の $\beta_{i}$ の決定のために Cressie 基準(17)を修正した次式(11)を用いる.

$$
W L S(\boldsymbol{\beta})=\sum_{k=1}^{K} \frac{\left|N_{k}\right|}{\gamma\left(\boldsymbol{h}_{k}, \boldsymbol{\beta}\right)}\left(\hat{\gamma}\left(\boldsymbol{h}_{k}\right)-8 \beta_{0}^{2}-\gamma\left(\boldsymbol{h}_{k}, \boldsymbol{\beta}\right)\right)^{2}
$$

ここで, Kは セミバリオグラムの同定に用いる集合の 数である.

2.3 多項式による方法 多項式を使った応答曲 面は, 応答曲面法による最適化では最も一般的に使用 されている(18).この方法では，使用する多項式の形式

(考慮する次数や項) を設定した後, 多項式による応 答と教師データ応答の 2 乗誤差が最小となるように多 項式中の未知係数を決定し, それを応答曲面とする. 例えば, 1 変数の場合, $n$ 次多項式を用いた次式が使わ れることが多い.

$$
f(x)=\sum_{i=0}^{n} a_{i} x^{i}
$$

ここで, $x$ は変数, $a_{i}$ は $i$ 次の項に関する係数である. 多項式による方法は, 変数の数が多くなると決定すべ き係数が多くなるという問題点がある. 一方で, 近似 応答曲面が直観的に把握しや寸いという利点を有し, 設計空間のスクリーニング(19)や大域的近似モデルの 併用による局所二次近似 ${ }^{(20)}$ などに用いられることも ある。

\section{3. 予貺精度の評価指攂}

本研究では，ノイズを含む教師データから作成した 応答曲面によって，ノイズを含まない真の応答がどの 程度の精度で予測できるかを調査する. したがって,
予測精度の評価指標として，応答曲面による応答の予 測值 $f(x)$ と真の応答 $f^{*}(x)$ の誤差を表すものを採用 する. 本報では, 次式の誤差の最大値 (MAX) と誤差 の平均値（RMS）で予測精度を評価した.

$$
\begin{aligned}
& \operatorname{MAX}=\max _{i}\left|f\left(x_{i}\right)-f^{*}\left(x_{i}\right)\right| \\
& \mathrm{RMS}=\sqrt{\frac{\sum_{i}\left(f\left(x_{i}\right)-f^{*}\left(x_{i}\right)\right)^{2}}{n}}
\end{aligned}
$$

ここで， $x_{i}$ は誤差を評価する位置であり,$n$ はその評 価位置の数である.

\section{1 变数関数の応答曲面近似}

$4 \cdot 11$ 変数関数の例題 1 変数関数の出力にノ イズを加えたデータを用意し，それを教師データとし て応答曲面を作成した. ここで，教師データの源であ る関数は，NN およびクリギングによる近似が適する と考えられる次式の多峰性の関数とした.

$$
f^{*}(x)=-x \sin (2 x)+0.2 x+1, \quad 0 \leq x \leq 5
$$

次節の予測精度の調查に一般性を持たせるため，振幅 の変化する正弦関数 $x \sin (2 x)$ と線形関数 $0.2 x$ を組み合 わせた規則性の無い関数を採用した.

$4 \cdot 2$ 1変数関数に対する予測精度 式(13)の関 数の出力に, 一様分布に従うノイズを加えたデータを 作成した. 一様分布に従うノイズは次式を使って発生 させた。

$$
U=(-1)^{P} \cdot \varepsilon \cdot p \cdot \max |f(x)|
$$

ここで, $U$ は一様分布ノイズ, $P$ は 0 を平均としてラ ンダムに発生させた整数, $p$ は $0<p<1$ の範囲でラン ダムに発生させた実数であり， $\varepsilon$ は 0.05 とした. この ようなデータを教師データとし, 応答曲面を作成した. 図 1 に式(13)の多峰性関数とともに, 応答曲面の作成 に使用した教師データを示す. 図 1(a), (b)の両教師デ 一タはデータの存在する $x$ 座標は同じである.ただし， 図1(b)の教師データでは， $x$ 座標の同じ位置にそれぞ れ3 個のデータが重複して存在し, データ数が図 1(a) の 26 個から 3 倍の 78 個となっている. 以降, 同じ $x$ 座標に重複してデータが存在する教師データを重複有 り教師データ，存在しない教師データを重複無し教師 
データと呼ぶ. データ数 26 個の場合と同様に, データ 数 11 個, 51 個の重複無し教師データと, データ数 33 個（=11 個 $\times 3 ）$ および 153 個（=51 個 $\times 3 ）$ の重複有 り教師データを用意した。一般的な通常クリギングは サンプル点間の補間を行うため, 重複有り教師データ では応答曲面を作成できない.

ベイズ推論を適用した NN(以降, B-NN と略記する), ns-Kriging および多項式を使用し, 各教師データから 応答曲面を作成した. 図 1(a)の教師データで応答曲面 を作成した結果を図 2 に示す，使用した $N N$ は，入力 層と出力層に加えて素子数 10 の中間層を含む3 層構造 である. B-NN, ns-Krigingによる応答曲面は教師デー タが含むノイズに適合していないことが理解できる. また, 図2(b)は式(10)の多項式による応答曲面であり,

“Poly-5”と “Poly-8” はそれぞれ次数 $n$ が 5 と 8 の場 合の結果を表している. 図 1 の多峰性関数は 4 点でそ の傾きがほぼ 0 となるので, 5 次の多項式を検討した. また，回帰分析で回帰式の適合度合いの評価に用いら れる自由度調整済み決定係数によると, 10 次までの多 項式の中で, 8 次の多項式の適合度が最も高かったの で, 8 次多項式についても調査した.

用意した各教師データで作成した応答曲面による

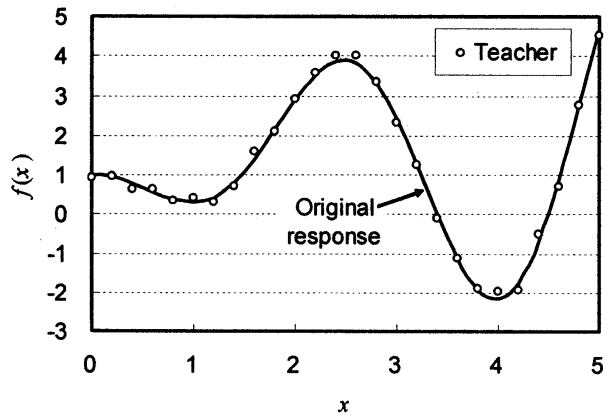

(a) Teacher data without overlap (26 data)

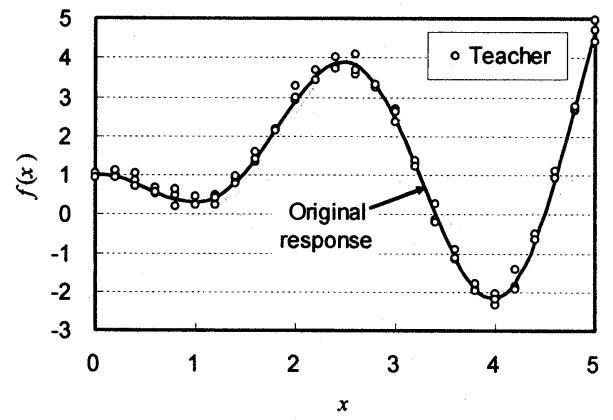

(b) Teacher data with overlap $(78(=26 \times 3)$ data $)$

Fig.1 Response of one-variable function and teacher data
予測精度を 3 章の評価指標（式(11)，(12)）で整理した 結果を表 1,2 に示す. 表中の各值は式(11),(12)の MAX, RMS を式(13)の応答の全変動 (二最大值一最小值) 6.88 と比較して求めた百分率である. また，表 1 の重複無 し教師データに関する RMS の変化傾向を図 3 に示す.

$4 \cdot 3$ 考察 教師データの数, データ重複の有無 に関わらず, ns-Kriging による応答曲面の予測誤差は B-NNによるものと比較して常に小さい. この傾向は 特に教師データ数が小さいときに影著である. クリギ ングはある点の応答を予測する際，全ての教師データ の情報を利用するため，教師データが少ない場合でも 有効な予測が可能であると考えられる. 少数データに 対するクリギングのこのような優位性は，本例題のよ うに予測が内挿領域で行われる場合に現れる，応答曲 面による予測が外挿領域に及ぶ場合については次節で 考察する. 一方, NN はある点の応答を精度良く予測 するためには，その点近傍にある程度の数の教師デー タが存在しなければならない. 教師データ数が少ない 場合は高精度の予測が困難になると考えられる.

$\mathrm{NN}$ の構造は，全ての教師データに対して，中間層 に 20 個の素子を持つ 3 層構造として学習を開始した. しかし, 教師デ一タ数が少ない場合, 2.1 節の手順に従

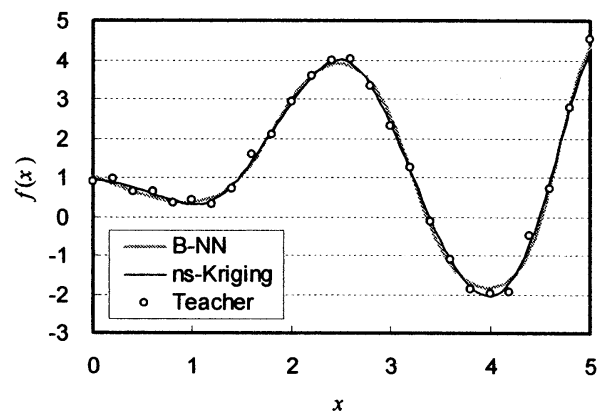

(a) B-NN and ns-Kriging

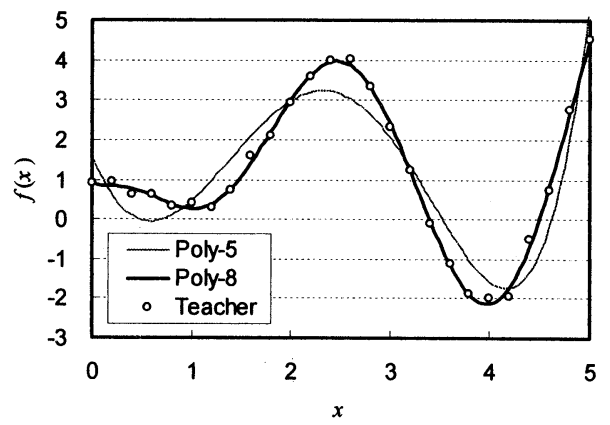

(b) Polynominal functions

Fig.2 Response surfaces of a one-variable function by using teacher data without overlap ( 26 data) 
Table 1 Average prediction error of response surfaces

\begin{tabular}{c|c|c|c|c}
\hline \multirow{2}{*}{$\begin{array}{c}\text { The number of } \\
\text { teacher data }\end{array}$} & \multicolumn{4}{|c}{ Response surface } \\
\cline { 2 - 5 } & B-NN & ns-Krig & Poly-5 & Poly-8 \\
\hline 11 & 7.17 & 3.18 & 9.28 & 1.73 \\
\hline 26 & 1.89 & 1.25 & 8.55 & 0.89 \\
\hline 51 & 1.06 & 0.81 & 8.14 & 0.73 \\
\hline $33(11 \times 3)$ & 3.30 & 1.98 & 9.09 & 1.53 \\
\hline $78(26 \times 3)$ & 1.59 & 0.87 & 8.42 & 0.80 \\
\hline $153(51 \times 3)$ & 1.41 & 0.84 & 8.19 & 0.63 \\
\hline & \multicolumn{4}{c}{ (Unit : \%) }
\end{tabular}

Table 2 Maximum prediction error of response surfaces

\begin{tabular}{c|c|c|c|c}
\hline The number of & \multicolumn{4}{|c}{ Response surface } \\
\cline { 2 - 5 } teacher data & B-NN & ns-Krig & Poly-5 & Poly-8 \\
\hline 11 & 12.91 & 9.50 & 17.55 & 4.51 \\
\hline 26 & 5.39 & 7.27 & 15.38 & 2.53 \\
\hline 51 & 3.42 & 2.55 & 22.94 & 2.41 \\
\hline $33(11 \times 3)$ & 13.58 & 7.33 & 17.45 & 5.54 \\
\hline $78(26 \times 3)$ & 3.93 & 1.79 & 14.90 & 1.91 \\
\hline $153(51 \times 3)$ & 5.48 & 3.81 & 20.34 & 2.05 \\
\hline
\end{tabular}

(Unit : \%)

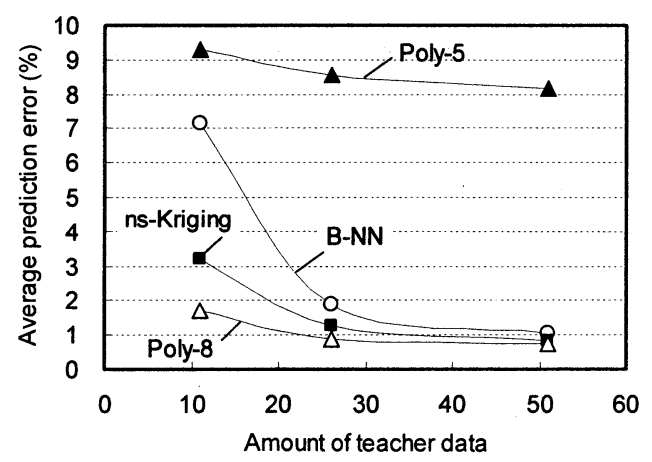

Fig.3 Average prediction error of response surfaces using teacher data without overlap

つて超パラメータが更新できないことがあり，その場 合は中間層の素子数を減少させて応答曲面を作成した. 具体的には重複無し教師データにおいて, データ数 11 個では中間層の素子数を 4 個, データ数 26 個では中間 層の素子数を 10 個として応答曲面を作成した. 中間層 の素子数が多くなると, NN は教師データが含むノイ ズに過剰適合しやすくなるが，ベイズ推論に従った学 習方法によってこのような過剰適合は防ぐことができ る. しかし, 教師データ数に比べて NN が含む未知係 数 (素子間の重み係数) の数が極めて多い場合, ベイ ズ推論に従った学習方法も有効に作用しなくなる.

ベイズ推論に基づく NN の学習では式(1)を最小化す るが, 式(1)はNNによる予測值と観測值 (教師データ) の誤差が正規分布に従うという仮定の下で導出される. したがって，ノイズが一様分布に従う場合は, ベイズ
推論に基づく学習は厳密には適用できないので, NN による応答曲面には高い予測精度を期待できない.こ れが NNによる応答の予測精度がクリギングより劣る 原因の一つと考えられたので，ノイズが正規分布に従 う場合についても検討した. しかし，正規分布ノイズ の場合も，NNよりクリギングによる応答の予測精度 が高かった. したがって，本例題の場合，ノイズが従 う分布形は予測精度の優劣と無関係である.

本例題では, 8 次の多項式で最も予測精度が良い結 果となった. これは適切に多項式の次数を選ぶことが できれば，多項式によって非常に予測精度の良い店答 曲面が作成できることを意味する. ただし，変数の数 が多くなると, 選択可能な多項式の形式が増えるため, 適切な多項式の選択が難しくなる.

\section{2 变数関数の応答曲面近似}

$5 \cdot 12$ 変数関数の例題 2 変数関数の出力にノ イズを加えたデータを用意し，それを教師データとし て応答曲面を作成した. ここでは応答曲面近似の対象 として, Jin ら ${ }^{(21)}$ が種々の近似モデルのベンチマークに 使用した関数のうち, 次式の関数を採用した.

$$
f^{*}(x, y)=0.5 x^{2}+y^{2}-x y-7 x-7 y
$$

図 4 に式(15)の応答を示す.

$5 \cdot 2$ 2变数関数に対する予測精度 実験計画法 の一つであるラテン超格子法で変数 $(x, y)$ の組み合わ せを 100 個選択し，各組み合わせに対して応答を計算 した. 選択した 100 個のサンプル点を図 5 に示す.こ の応答に式(14)による一様分布ノイズを加算してノイ ズを含む教師データとし，それを使って B-NN と ns-Kriging で 2 変数の応答曲面を作成した. 式(11), (12) の予測精度の評価指標を 2 変数に拡張し, 予測誤差を 計算した結果を表 3 に示す。“LH” の行が図 5 のサン プル点で応答曲面を作成した場合の結果であり，表中 の各值は式(11), (12)の MAX, RMS を式(15)の応答の 全変動 (=最大値一最小值) 4122.5 と比較して求めた 百分率である. ここで， $x, y$ 方向ともに間隔 1 で誤差 の評価位置を定めて予測誤差を計算した. また, B-NN と ns-Kriging による応答の予測值 $f(x, y)$ と真の応答值 $f^{*}(x, y)$ の誤差の分布を次式の $\operatorname{Er}(x, y)$ で計算し, そ れを百分率で表した結果を図 6 に示す.

$$
\operatorname{Er}(x, y)=\frac{\left|f(x, y)-f^{*}(x, y)\right|}{\max f^{*}-\min f^{*}}
$$




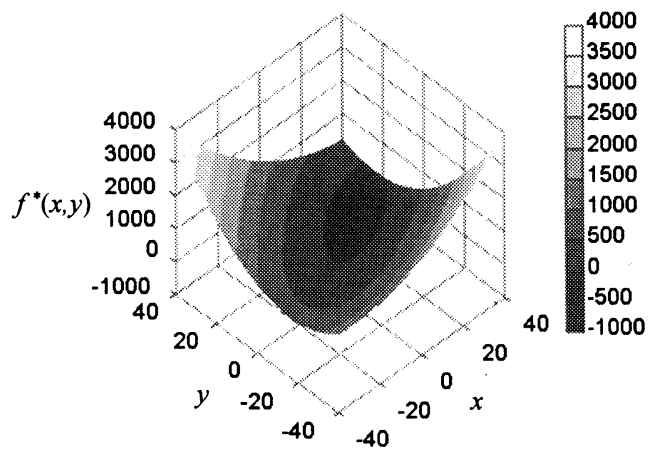

Fig.4 Response of two-variable function

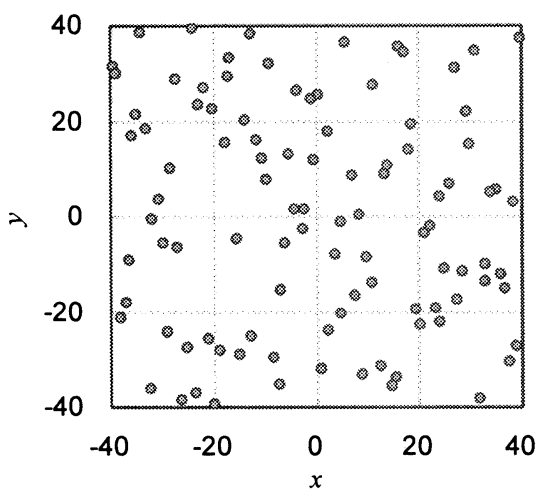

Fig.5 Sample points for two-variable function by using Latin hypercube method

$5 \cdot 3$ 考察 表 3 より, 本例題では B-NN による応 答曲面の予測誤差は ns-Kriging によるものと比較して 小さい. 特に, ns-Krigingによる最大予測誤差はB-NN と比べてかなり大きい. 図6より, ns-Kriging で予測誤 差が大きいのは $(x, y)=(40,-40),(-40,40)$ の近傍であ ることがわかる.これらの領域は応答の勾配が急であ り, 教師データ（サンプル点）の密度が低く, かつ応 答予測が外挿となる領域である. 通常クリギングは一 般的に外挿領域の応答予測が得意でない. そのため, 通常クリギングを用いた ns-Kriging も B-NN に比べて 外挿能力が劣る結果になったと推定できる. 一方, 設 計空間の大半を占める内挿領域では B-NN, ns-Kriging ともに応答曲面による予測値と真の応答の差は $3 \% よ$ り小さい. このことは, ns-Kriging を使用する場合, 予 測したい領域が全て内挿となるように教師データを選 択すれば良いことを示唆している.

そこで，設計空間の境界にサンプル点を配置して応 答曲面を作成し，予測誤差がどのように変化するかを 調査した．新たなサンプル点の配置を図 7, 予測誤差 の MAX と RMS を表 3 (“LH+ Boundary”), ns-Kriging
Table 3 Prediction error of two-variable response surfaces

\begin{tabular}{c|c|c|c|c}
\hline & \multicolumn{2}{|c|}{ Average error } & \multicolumn{2}{c}{ Maximum error } \\
\cline { 2 - 5 } & $\mathrm{NN}$ & Kriging & $\mathrm{NN}$ & Kriging \\
\hline $\mathrm{LH}$ & 0.77 & 1.95 & 12.73 & 28.47 \\
\hline $\mathrm{LH}+$ Boundary & 0.54 & 1.18 & 3.14 & 7.94 \\
\hline
\end{tabular}

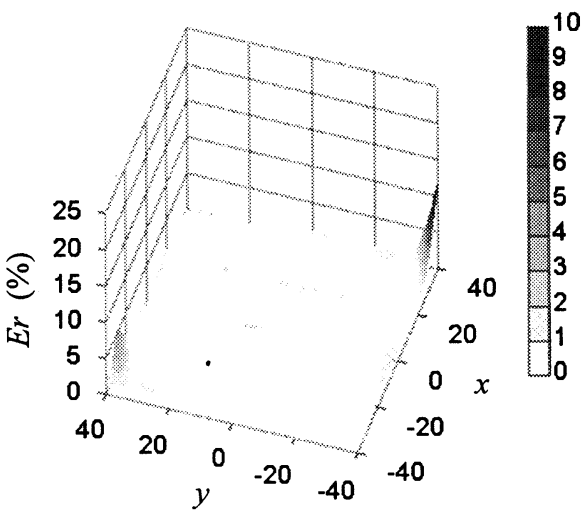

(a) $\mathrm{B}-\mathrm{NN}$

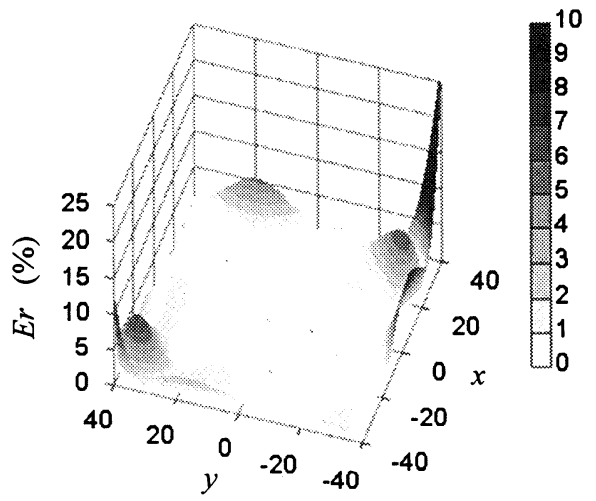

(b) ns-Kriging

Fig.6 Prediction error distribution for two-variable function

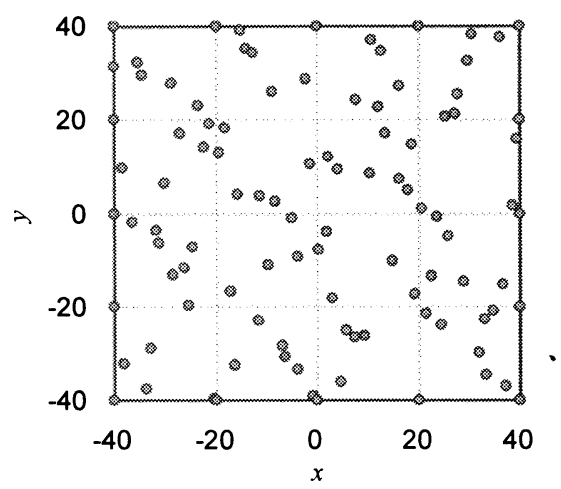

Fig. 7 Sample points for two-variable function by using Latin hypercube method and point placement on boundary 


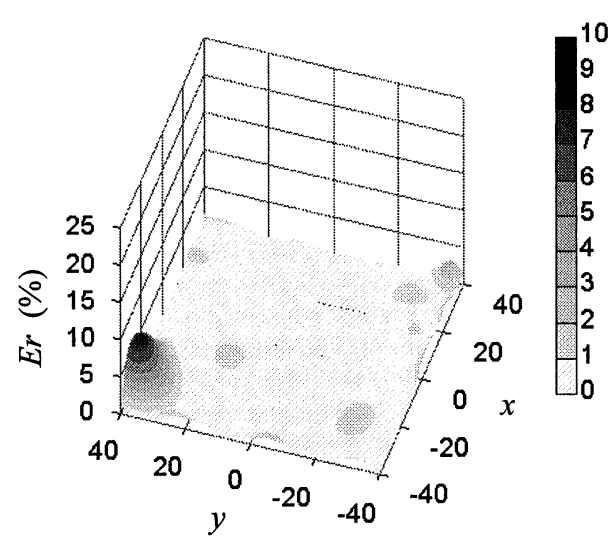

Fig. 8 Prediction error distribution of ns-Kriging response surface for two-variable function

による応答と真の応答の誤差分布を図 8 に示す. サン プル点を境界上に配置したことにより, ns-Krigingに よる応答曲面の最大予測誤差は $28.74 \%$ から $7.94 \%$ 一 と大幅に改善された. 図 8 より, 設計空間の境界近傍 で誤差の減少が明確に認められる.

このように，サンプル点の境界上への配置により， ns-Kriging でも精度の良い応答曲面の作成が可能であ る.このような配慮が無い場合, 変数の数が多くなる と，必然的に応答曲面に占める外挿領域（設計空間の 境界など）が増えるため, ns-Kriging よりも B-NNによ る応答曲面近似が有利になると推測できる.

\section{6. 工学的設計問題人の適用例}

6・1 工学的設計問題 図9のように, 板から 2 本のはりが立て付けられ，そのはりが互いに接続され た構造を考える.このはりの中心軸は鋼製であり, 中 心軸の周りは GFRP (Glass fiber reinforced plastics) で覆 われている.このような構造で, 取り付け部を一定の 加速度 $\left(9.8 \mathrm{~m} / \mathrm{s}^{2}\right)$ でスイープ加振したとき, はりの最 低次の固有振動数がある周波数以上であり, かつ共振 点ではり先端の変位が最大となる, はりの径と板の厚 さを求める. 設計変数は具体的に, (1)はりの中心軸径, (2)GFRP の厚さ，(3)り締結部の板厚, (4)取り付け部 の板厚, の 4 箇所の寸法とし, 各変数は 4 水準の值を とり得るとする.

(1)はり中心軸径 $=\{6 \mathrm{~mm}, 8 \mathrm{~mm}, 10 \mathrm{~mm}, 12 \mathrm{~mm}\}$ (2) GFRP 厚さ $=\{2 \mathrm{~mm}, 3 \mathrm{~mm}, 4 \mathrm{~mm}, 5 \mathrm{~mm}\}$

(3)はり締結部の板厚 $=\{6 \mathrm{~mm}, 9 \mathrm{~mm}, 12 \mathrm{~mm}, 15 \mathrm{~mm}\}$

(4)取り付け部の板厚 $=\{6 \mathrm{~mm}, 9 \mathrm{~mm}, 12 \mathrm{~mm}, 15 \mathrm{~mm}\}$
このような設計問題の解を得る一つの手段として, 次の方法が考えられる. すなわち, まず実験計画法で 実験計画を策定し，各実験に対応した構造を製作して スイープ加振を行い, 着目する応答を測定する. 続い て, その応答の測定結果をもとに応答曲面を作成し, その応答曲面で未測定の応答を予測しながら最も目的 に合った構造寸法を明らかにする. 以降，この方法に 従って解を求める.

ここでは, 実験計画として L16 直交表(22)を採用した. そして, 実験の代わりに数值解析で応答（はりの最低 次の固有振動数, はり先端変位) を求め, それにノイ ズを加えて測定データとみなした. 同一分布に従う 3 個のノイズを用意し，それぞれを数值解析による応答 に加算することで, L16 の各実験に対して 3 個ずつの 仮想測定データを作成し, 合計 48 個の測定データを用 意した. ここで, 固有振動数に対しては平均 $0 \mathrm{~Hz}$, 標 準偏差 $10 \mathrm{~Hz}$ の正規ノイズ, はり先端変位に対しては 平均 $0 \mathrm{~mm}$, 標淮偏差 $0.005 \mathrm{~mm}$ の正規ノイズを加算し た. $10 \mathrm{~Hz}$ は固有振動数の $3.5 \%$ (教師データ平均), $0.005 \mathrm{~mm}$ ははり先端変位の $15.2 \%$ (教師データ平均) に相当する値である.

6・2 応答曲面と最適解 準備した測定データを 教師データとし, B-NN と ns-Kriging で応答曲面を作成 した. 図 10 は, 3 変数を固定し (1) $=6 \mathrm{~mm}$, (2) $=3 \mathrm{~mm}$, (4) $=9 \mathrm{~mm}$ ），1 変数（3) を変化させて, B-NNおよ び ns-Kriging による応答曲面と真の応答（ノイズを含 まない数值解析による応答）を比較したものである. 図中の “Orig. response” は真の応答を意味する. B-NN による応答の予測值は ns-Kriging によるものよりも真 の応答と良く一致している.

B-NN およびns-Kriging による応答曲面を使用し, 固 有振動数が $250 \mathrm{~Hz}$ 以上，かつ (3) > (4)という制約条 件の下, 共振点での変位が大きい順に選択した 5 組の 構造寸法とその応答值を表 4, 5 に示す. 表中の “Orig.” は真の応答を意味する. B-NN, ns-Kriging に関わらず, 応答曲面の予測誤差が原因で, 固有振動数が $250 \mathrm{~Hz}$ 末 満の組み合わせも選ばれているが, $250 \mathrm{~Hz}$ 以上(表中, 灰色で網掛け）を満足し，かつ共振点変位の大きな構 造寸法（表 4，5の No.3）が明らかとなった.

$6 \cdot 3$ 考察 本設計問題の教師データの数は 48 個, 変数の数は 4 個であり, 前章の 2 変数関数の例題 に比べてさらに応答曲面が外挿しなければならない領 域が増加している.これが ns-Kriging による応答曲面 近似を難しくした原因と推測できる. 実際 Sakata らは, サンプル点の数が少ない場合, ns-Kriging では応答の予 測精度が悪化する恐れがあるため, 応答曲面で制約条 
件を近似する最適化問題には, ns-Kriging を慎重に適用 すべきという見解を示している(23).

外挿となる領域を減らすため, 設計空間の隅にサン プル点 (ここでは仮想測定データ)を追加し, ns-Kriging て応答曲面を作成した. 4 変数の場合, 設計空間の隅 は 16 ヶ所あるが, L16 直行表による実験計画で設計空 間の隅 2 ケ所に既にサンプル点を配置していたため, その2 ケ所を除く 14 ヶ所に新たにサンプル点を配置し た. 各ヶ所にノイズの大きさの異なる 3 個のサンプル 点を追加したので, 追加したサンプル点は合計 42 個で ある. このサンプル点で作成した ns-Kriging による応 答曲面を図 11 に示寸. 図 11 では, 図 10 と同様に,

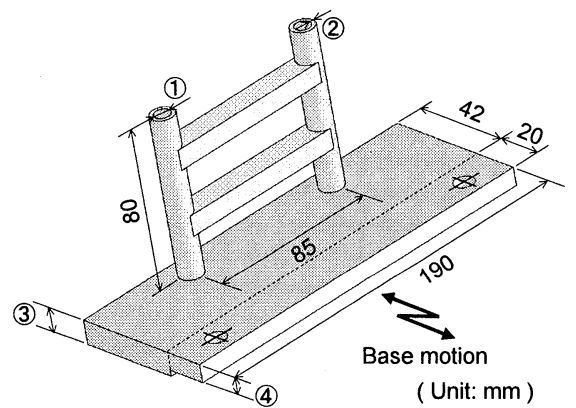

Fig. 9 Structure including two rods connected to each other

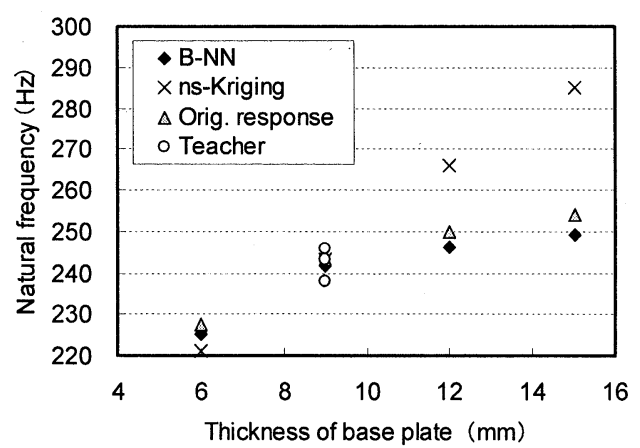

(a) Natural frequency

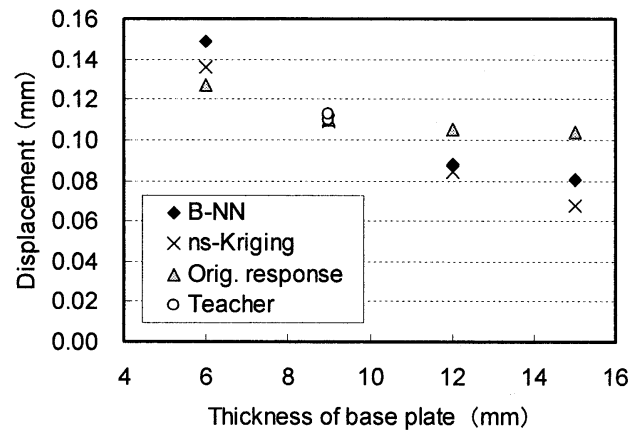

(b) Displacement at resonance frequency

Fig.10 Response surface of NN, Kriging, original response, and teacher data (1) $=6 \mathrm{~mm}$, (2) $=3 \mathrm{~mm}$, (4) $=9 \mathrm{~mm}$ )
3 変数を固定し (1) $=6 \mathrm{~mm},(2)=3 \mathrm{~mm}$, (4) $=9 \mathrm{~mm})$, 1 変数（3) を変化させた. 図中の “ns-Kriging(BS)" が設計空間の隅にサンプル点を配置した場合の応答曲 面である. 設計空間の隅へのサンプル点配置により, 応答曲面の精度が大きく向上することがわかる.この ns-Kriging による応答曲面を使用し, 固有振動数 $250 \mathrm{~Hz}$ 以上, かつ (3) > (4)という制約条件の下, 共振点での 変位が大きい順に選択した 5 組の構造寸法とその応答 值を表 6 に示す. 4 組（表中, 灰色で網掛け）が制約 条件 $250 \mathrm{~Hz}$ 以上を満足し, 共振点での変位が $0.105 \mathrm{~mm}$ となる解（表 6 の No.4）が選ばれており, サンプル点 を設計空間の隅に追加する前に比べて優れた解が見つ かったことがわかる.

以上から，ノイズを含む測定データをもとにした設 計問題に対し, サンプル点の配置に配慮すれば, B-NN および ns-Kriging による応答曲面によって, 目的に応 じた構造を得ることができると考える.

\section{7. 結言}

教師データがノイズを含む場合でも有効な $\mathrm{NN}$ およ びクリギングによる応答曲面の作成方法を利用して, 1 変数関数および 2 変数関数の応答曲面を作成した. ま た, 測定データから応答曲面を使って目的に応じた解 を見つける設計問題に両手法を適用し, 手法の有効性 を検証した. 得られた知見を以下にまとめる.

Table 4 Geometry obtained by using B-NN

\begin{tabular}{c|c|c|c|c|c}
\hline \multirow{2}{*}{ No. } & \multirow{2}{*}{$\begin{array}{c}\text { Geometry } \\
\text { (1,2,3), (4) }\end{array}$} & \multicolumn{2}{|c|}{ Natural frequency } & \multicolumn{2}{c}{ Displacement } \\
\cline { 3 - 6 } & B-NN & Orig. & B-NN & Orig. \\
\hline 1 & $6,2,12,9$ & 257 & 222 & 0.098 & 0.155 \\
\hline 2 & $6,5,9,6$ & 253 & 275 & 0.087 & 0.059 \\
\hline 3 & $6,4,15,6$ & 259 & 275 & 0.087 & 0.074 \\
\hline 4 & $8,2,12,6$ & 262 & 273 & 0.084 & 0.070 \\
\hline 5 & $6,2,15,9$ & 256 & 224 & 0.083 & 0.153 \\
\hline
\end{tabular}

(Unit: Geometry, Displacement ( $\mathrm{mm})$, Natural frequency $(\mathrm{Hz})$ )

Table 5 Geometry obtained by using ns-Kriging

\begin{tabular}{c|c|c|c|c|c}
\hline \multirow{2}{*}{ No. } & Geometry & \multicolumn{2}{|c|}{ Natural frequency } & \multicolumn{2}{c}{ Displacement } \\
\cline { 3 - 6 } & (1,2,3),4 & ns-Krig & Orig. & ns-Krig & Orig. \\
\hline 1 & $6,5,9,6$ & 256 & 275 & 0.110 & 0.059 \\
\hline 2 & $6,3,12,6$ & 259 & 244 & 0.107 & 0.112 \\
\hline 3 & $8,3,9,6$ & 258 & 273 & 0.098 & 0.061 \\
\hline 4 & $6,2,15,6$ & 266 & 220 & 0.096 & 0.161 \\
\hline 5 & $6,2,12,9$ & 255 & 222 & 0.096 & 0.155 \\
\hline
\end{tabular}

(Unit: Geometry, Displacement ( $\mathrm{mm})$, Natural frequency $(\mathrm{Hz})$ ) 


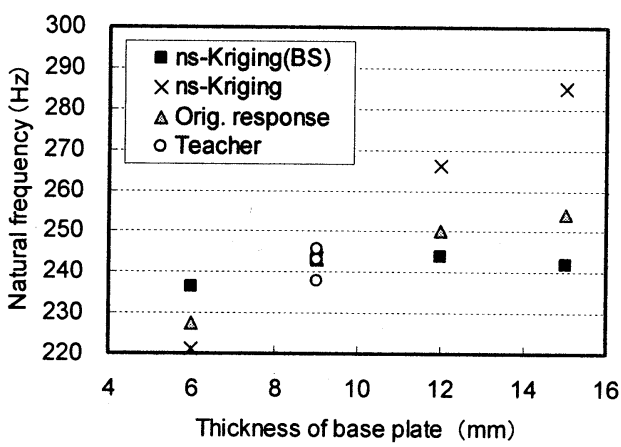

(a) Natural frequency

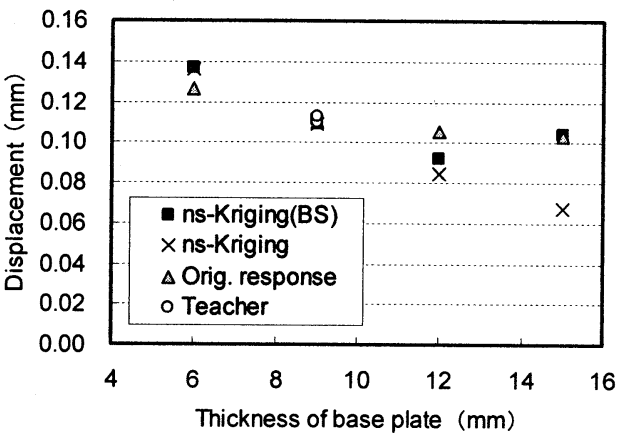

(b) Displacement at resonance frequency

Fig.11 Response surface of Kriging with boundary sampling points, original response, and teacher data (1) $=6 \mathrm{~mm}$, (2) $=3 \mathrm{~mm}$, (4) $=9 \mathrm{~mm}$ )

Table 6 Geometry obtained by using ns-Kriging with boundary sampling points

\begin{tabular}{c|c|c|c|c|c}
\hline \multirow{2}{*}{ No. } & \multirow{2}{*}{$\begin{array}{c}\text { Geometry } \\
\text { (1), 2,3,4) }\end{array}$} & \multicolumn{2}{|c|}{ Natural frequency } & \multicolumn{2}{c}{ Displacement } \\
\cline { 3 - 6 } & ns-Krig & Orig. & ns-Krig & Orig. \\
\hline 1 & $6,3,12,6$ & 257 & 244 & 0.127 & 0.112 \\
\hline 2 & $6,3,15,9$ & 261 & 254 & 0.116 & 0.103 \\
\hline 3 & $8,2,12,6$ & 274 & 273 & 0.109 & 0.070 \\
\hline 4 & $6,3,12,9$ & 262 & 250 & 0.109 & 0.105 \\
\hline 5 & $6,3,15,12$ & 259 & 256 & 0.108 & 0.102 \\
\hline
\end{tabular}

(Unit: Geometry, Displacement (mm), Natural frequency $(\mathrm{Hz})$ ).

(1) 多峰性 1 変数関数の応答曲面を, ノイズを含む教 師データから作成する場合, B-NN よりも ns-Kriging の方が応答の予測精度は良い.この傾向は特に教師 データ数が少ない場合に顕著であり, ns-Kriging の内 挿能力の高さに起因するものである.

(2) 変数が多くなると, B-NNに比べて ns-Kriging によ る応答の予測精度は悪くなる.ただし，この予測精 度の悪化は予測が外挿となる領域に限られるため, 外挿領域が小さくなるように教師データを配置すれ
ば, 多変数の場合でも ns-Kriging を用いて精度の良い 応答曲面が作成できる.

(3) 測定データをもとに目的に応じた解を求める工学 的設計問題に B-NN と ns-Kriging を適用したところ, 制約条件を満たす解が探索できた．したがって，両 手法はノイズを含むデータをもとに目的に応じた解 を求める際に有効な方法である.

\section{文献}

(1) Box, G. E. P. and Wilson, K. B., Journal of the Royal Statistical Society, Series B, 13(1951), pp. $1-45$

(2) Hagiwara, I. et al., Transactions of the Japan Society of Mechanical Engineers, Series A, Vol. 63, No. 616 (1997), pp. 46-53.

(3) Sakamoto, R. et al., Quarterly Journal of the Japan Welding Society, Vol.24, No.1 (2006), pp. 93-99.

(4) Sacks, J. et al., Statistical Science, Vol. 4, No. 4(1989), pp. 409-435.

(5) Simpson, T. W. et al., AIAA-98-4755(1998), pp.381-391.

(6) Mullar, A. A. and Messac A., AIAA Journal, Vol. 43, Issue 6(2005), pp. 1306-1315.

(7) Sakata, S. et al., Computer Methods in Applied Mechanics and Engineering, Vol. 193 (2004), pp. 385-404.

(8) Funahashi, K., The institute of Electronics, Information and Communication Engineers, Technical Report, MBE 88-9(1988), pp.59-65.

(9) Hertz, J. et al., Introduction to the Theory of Neural Computation (1991), p.147, Addison-Wesley.

(10) Sasena, M. et all, DETC'02 ASME, DET2002/ DAC-34091.

(11) Sakata, S. et all, Computer Methods in Applied Mechanics and Engineering, Vol. 196, Issues 13-16(2007), pp. 2055-2069.

(12) MacKay, D.J.C., Neural Computation, Vol. 4 (1992), pp. 413-447.

(13) MacKay, D.J.C., Neural Computation, Vol. 4 (1992), pp. 448-472.

(14) Takeda, N., Transactions of the Japan Society of Mechanical Engineers, Series A, Vol.73, No.733 (2007), pp. 1079-1086.

(15) Wackernagel H., Multivariate Geostatistics(2003), Springer.

(16) Mase S. and Takeda J., Spatial Data Modeling (2001) ,Kyoritsu Shuppan Co. LTD (in Japanese)

(17) Cressie, N., Mathematical geology, Series A, Vol.17, No.5 (1985), pp. 563-586.

(18) Myers, R. H. and Montgomery, D. C., Response Surface Methodology (1995), John Wiley \& Sons.

(19) Wang, G. G. and Simpson, T. W., Engineering Optimization, Vol.36, 3(2004), pp.313-335.

(20) Sakata, S. et al., International Journal for Numerical Methods in Engineering, Vol.70(2007), pp.631-654.

(21) Jin, R., Chen, W. and Simpson, T. W., Structural and Multidisciplinary Optimization, Vol. 23, No. 1-3(2001), pp.1-13.

(22) Peace, G. S., Taguchi Methods: A Hands-on Approach, (1993), p.117, Addison-Wesley.

(23) Sakata, S. et al., Computational Mechanics, Vol.31(2003), pp.409-418. 